\title{
POTASSIUM STATUS IN THE SOILS OF BAHTIM PERMANENT EXPERIMENT UNDER DIFFERENT CROP ROTATIONS AND FERTILIZER TREATMENTS
}

\author{
AHMED, HODA M. R. M, ENSHRAH I. M. ELMAAZ and H. M. KHALIL
}

Soils, Water and Environ. Res. Inst., ARC, Giza, Egypt

(Manuscript received 24 July 2014)

\begin{abstract}
Composite surface soil samples were taken from plots (Bahtim permanent experiment) receiving mineral and farmyard (FYM) fertilizers treatments in case of the one-, two- and three-year rotations. These soil samples represent the impact of subjecting such soils for about 100 years to prolonged cropping and fertilization treatments. Soluble, exchangeable, plant available potassium in conjunction with the potassium intensity of these soils were determined. Moreover, the K-fixation capacity was considered in this study. The obtained data show an obvious decrease in potassium forms in case of the two- and three-year rotation compared with their levels in the one- year rotation. This depends on the crops grown in every rotation.

The decrease in K- availability in soils have its impact on crop response to $\mathrm{K}$ - applications. This trend should be considered in managing the fertilization programs in the old lands.
\end{abstract}

\section{INTRODUCTION}

Soil potassium occurs in soluble, exchangeable and difficulty exchangeable forms that are differentiated from one another by the strength or closeness of their linkages with the system of clay minerals and organic matter. The water - soluble and exchangeable forms are considered the immediate available sources for plant uptake, however, the plants are able to absorb the difficulty- exchangeable forms too (Talibundeen and Rajendran, 1969; Hamdi et. al.; 1971, Barber, 1984 and Madaras and Lipavsky 2009).

The Egyptian soils are considered rich in their total and available- $K$, consequently the yields of crops receiving $\mathrm{K}$-applications were not affected significantly (El-Damaty and El-Baradhy 1959). Nowadays the use of the high yielding crop varieties and the application of high nitrogen levels in conjunction with the high cropping intensity will enhance the potassium resources exhaustion and a response to K-application might exist.

The long-term field experiments of Bahtim permenant experiment (1912-2013) help in evaluating the impact of applying different agronomic practices on soil production sustainability. In this concern, Fayed and Rateb (2013) concluded that cropping systems may influence the content and distribution of soluble salts, organic matter, available macro and micronutrients through fertilization systems and organic manure application. 
Monitoring the changes of different factors affecting productivity (soil physical and chemical properties, fertility status and crop response to applied fertilizers ....etc.) are of high importance for sustainable Egyptian agriculture assessment.

The present study aims to follow up the impact of applying different rotations, farmyard manure and mineral fertilizers on soil fertility status where potassium availability, released values and also K-fixation values represent vital factors in soil fertility determination.

\section{MATERIALS AND METHODS}

Composite surface soil samples $(0-30 \mathrm{~cm}$ depth) were taken from plots receiving the mineral and farmland manure (FYM) fertilizers treatments after cotton harvest in 2013 in case of the one-, two- and three-year rotations (Bahtim permanent experiment). The soil samples were air dried and ground to pass a $2 \mathrm{~mm}$ sieve. Soil characteristics are shown in Table (1). The following treatments were included in the experiment:

\section{a- Rotations treatments}

1- One-year rotation: Cotton every year.

2- Two-year rotation: Cotton (in the first year). Wheat followed by corn (in the second year).

3- Three-year rotation: Cotton (in the first year). Berseem followed by corn (in the second year). Wheat followed by corn (in the third year).

\section{b- Fertilization treatments}

1- Control 2- N 3-NP 4-NPK 5-Farmyard manure (FYM).

Moreover, the fertilization rate per feddan (fed) for the different crops is applied as follows:

Berseem: No fertilization. Cotton or wheat: 100 kgs sodium nitrate $(15.5 \% \mathrm{~N}), 125$ kgs super phosphate $\left(15.5 \% \mathrm{P}_{2} \mathrm{O}_{5}\right)$ and $100 \mathrm{kgs}$ potassium sulphate (48 $\% \mathrm{~K}_{2} \mathrm{O}$ ).

Corn: $150 \mathrm{kgs}$ sodium nitrate.

Since 2000 , ammonium nitrate $(33.5 \% \mathrm{~N})$ is used as nitrogen source. Farmyard application is applied with a level of 15 Tons/feddan for cotton, wheat and corn (Aladjem, 1952 and Heggy, 1976).

Exchangeable- $\mathrm{K}$ was determined using normal- $\mathrm{N}$ solution of ammonium acetate. The plant available- $\mathrm{K}$ was determined using $\mathrm{H}_{2} \mathrm{SO}_{4}$ extraction (Hunter and Pratt, 1957).

The $\mathrm{K}$ retention capacity of the studied soil samples was determined using the wet method described by Schuffelen and Van der Marel (1955). 
Table 1. Particle size distribution, O. M. \% and T.S.S. \% values of Bahtim permanent experiment soils after cotton harvest in 2013 .

\begin{tabular}{|c|c|c|c|c|c|c|c|c|c|c|c|c|c|c|c|}
\hline \multirow[t]{2}{*}{ Item* } & \multicolumn{5}{|c|}{ One-year rotation } & \multicolumn{5}{|c|}{ Two-year rotation } & \multicolumn{5}{|c|}{ Three-year rotation } \\
\hline & Control & $\mathbf{N}$ & NP & NPK & FYM & Control & $\mathbf{N}$ & NP & NPK & FYM & Control & $\mathbf{N}$ & NP & NPK & FYM \\
\hline Coarse sand \% & 0.22 & 1.86 & 1.71 & 2.60 & 2.09 & 1.86 & 1.17 & 1.75 & 2.23 & 1.63 & 1.41 & 1.13 & 1.48 & 2.07 & 1.74 \\
\hline Fine sand $\%$ & 24.04 & 22.98 & 22.83 & 21.25 & 28.78 & 20.46 & 20.88 & 25.71 & 25.21 & 26.22 & 21.96 & 19.51 & 20.34 & 22.35 & 25.70 \\
\hline Silt \% & 24.81 & 25.13 & 26.39 & 27.35 & 31.22 & 25.19 & 24.77 & 20.89 & 27.03 & 22.14 & 24.66 & 24.68 & 26.62 & 26.67 & 23.65 \\
\hline Clay \% & 47.38 & 46.68 & 45.30 & 45.15 & 40.27 & 49.40 & 49.95 & 48.24 & 41.88 & 47.50 & 48.69 & 51.49 & 47.98 & 45.62 & 42.82 \\
\hline $\mathrm{CaCO}_{3} \%$ & 3.24 & 3.15 & 3.41 & 3.65 & 2.48 & 2.95 & 3.04 & 3.42 & 3.33 & 3.25 & 3.10 & 2.95 & 3.46 & 3.07 & 3.48 \\
\hline T.S.S. \% * & 0.23 & 0.21 & 0.26 & 0.27 & 0.19 & 0.19 & 0.24 & 0.26 & 0.29 & 0.23 & 0.22 & 0.31 & 0.27 & 0.24 & 0.24 \\
\hline
\end{tabular}

*T.S.S. \%: Total soluble salts, $\quad * *$ O.M. \%: Organic matter 
The soil potassium intensity is measured by equilibrating five grams of soil with $50 \mathrm{ml}$ of 0.002 molar $\mathrm{CaCl}_{2}$ solution. The actual concentration of $\mathrm{K}, \mathrm{Ca}$ and $\mathrm{Mg}$ (mole/L) in the filtrate is transformed into activities to be used in the equation: a $\mathrm{K}$ [a $(\mathrm{Ca}+\mathrm{Mg})^{-1 / 2}$ ] where a means; activity $\mathrm{K}, \mathrm{Ca}$ and $\mathrm{Mg}$ denotes the activity of these ions. The activity ratio is expressed in the logarithmic form as follows: $\mathrm{p} \mathrm{K}-0.5 \mathrm{p}$ ( $\mathrm{Ca}+$ Mg), (Woodruff, 1955 and Beckett, 1964).

According to the classification given by woodruff (1955) the soil is considered to represent potassium deficiency or adequacy or excess when it has a potassium intensity of $2.57,2.20$ or 1.47 , respectively.

\section{RESULTS AND DISCUSSION}

Soil fertility status has its impact on production sustainability which is also affected by the application of different agronomic practices. The long-term experiment is considered an important tool in evaluating the impact of prolonged application of these practices on production sustainability for next generation (Behera et. al., 2009). According to this approach, the soils of Bahtim permanent experiment were subjected to different treatments for more than 100 years such as crop rotation systems in conjunction with farmyard manure and mineral fertilization treatments. The total applied amounts of organic and mineral fertilizers and seasons of growing different crops during 100 years are shown in Table (2). The obtained data in this study is concerned with the status of potassium as a factor involved in determining soil fertility and crop production sustainability.

\section{1- Potassium status in soil as affected by different rotations}

\subsection{Soluble and exchangeable-K}

Data presented in Table (3) reveal that soil soluble $-\mathrm{K}$ exists with a mean of 0.062 , 0.040 and $0.037 \mathrm{meq} / 100 \mathrm{~g}$ soil, whereas the exchangeable- $\mathrm{K}$

Table 2. Total applied amounts of nitrogen, $\mathrm{P}_{2} \mathrm{O}_{5}$ and $\mathrm{K}_{2} \mathrm{O}(\mathrm{kg} / \mathrm{fed})$, farmyard manure (ton/fed) and seasons of growing different crops in Bahtim permanent experiment plots during 1912-2013.

\begin{tabular}{|l|c|c|c|}
\hline Item & One-year rotation & Two-year rotation & Three-year rotation \\
\hline Elemental nitrogen & 1454 & 2309 & 1919 \\
\hline $\mathbf{P}_{\mathbf{2}} \mathbf{O}_{\mathbf{5}}$ & 1918 & 2964 & 2403 \\
\hline $\mathbf{K}_{\mathbf{2}} \mathbf{O}$ & 4752 & 6912 & 5040 \\
\hline Farmyard manure(ton/fed) & 1455 & 1455 & 1455 \\
\hline Seasons of growing cotton & 97 & 48 & 32 \\
\hline Seasons of growing wheat & - & 48 & 32 \\
\hline Seasons of growing maize & - & 48 & 64 \\
\hline
\end{tabular}

Zanaty and Khalil (2014).

average amounts are $0.916,0.654$ and $0.436 \mathrm{meq} / 100 \mathrm{~g}$ soil for the one-, two- and three- year rotations, respectively. 
The highest values of both soluble and exchangeable- $K$ were recorded in case of the one-year rotation treatment. A decrease in soluble- $K$ values by $35.48 \%$ and 40.32 $\%$, and also in case of exchangeable- $\mathrm{K}$ by $28.60 \%$ and $51.52 \%$ exists in the twoand three-years rotations, respectively, compared with the one-year rotation.

\subsection{Plant available-K.}

The exhaustive cropping technique provides the most ideal means of estimating the difficulty-exchangeable $\mathrm{K}$ reserves; however it can take several months (Reitemeier, 1951). In case of this technique, the portion of $\mathrm{K}$ derived from the exchangeable form decreases to a point after which no further loss in the exchangeable form could occur. The solubility of the difficulty exchangeable form values of plant available- $\mathrm{K}$ determined using $\mathrm{H}_{2} \mathrm{SO}_{4}$ extraction is closer to $\mathrm{K}$-values using the standard intensive cropping technique according to Hunter and Pratt (1957) and Zanaty (1970).

Table 3. Soil-potassium status (meq/100 g soil) of Bahtim permanent experiment. after cotton harvest in 2013 (composite soil samples).

\begin{tabular}{|c|c|c|c|c|c|c|c|}
\hline \multirow[b]{2}{*}{$\begin{array}{l}\text { K-fractions } \\
\text { (meq/100g soil) }\end{array}$} & \multicolumn{7}{|c|}{ Fertilizer treatments } \\
\hline & Control & $\mathbf{N}$ & NP & NPK & FYM $^{*}$ & Mean & $\begin{array}{c}\text { Mean of } \\
\text { mineral } \\
\text { fert. }\end{array}$ \\
\hline \multirow{6}{*}{$\begin{array}{l}\text { Soluble-K } \\
\text { Exchangeable-K } \\
\text { Plant available-K }\left(\mathrm{H}_{2} \mathrm{SO}_{4}\right) \text { extraction } \\
\text { Fixation capacity } \\
\text { Potassium intensity }\end{array}$} & \multicolumn{7}{|c|}{ One- Year Rotation } \\
\hline & 0.58 & 0.052 & 0.058 & 0.080 & 0.064 & 0.062 & 0.063 \\
\hline & 0.770 & 0.846 & 0.846 & 1.116 & 1.000 & 0.916 & 0.936 \\
\hline & 1.038 & 1.026 & 1.064 & 1.224 & 1.250 & 1.120 & 1.105 \\
\hline & 1.982 & 1.963 & 1.968 & 1.971 & 1.955 & 1.968 & 1.967 \\
\hline & 2.583 & 2.649 & 2.583 & 2.520 & 2.519 & 2.571 & 2.584 \\
\hline \multirow{6}{*}{$\begin{array}{l}\text { Soluble-K } \\
\text { Exchangeable-K } \\
\text { Plant available-K }\left(\mathrm{H}_{2} \mathrm{SO}_{4}\right) \text { extraction } \\
\text { Fixation capacity } \\
\text { Potassium intensity }{ }^{* *}\end{array}$} & \multicolumn{7}{|c|}{ Two- Year Rotation } \\
\hline & 0.025 & 0.025 & 0.032 & 0.032 & 0.086 & 0.040 & 0.030 \\
\hline & 0.654 & 0.488 & 0.770 & 0.590 & 0.770 & 0.654 & 0.616 \\
\hline & 0.846 & 0.801 & 0.917 & 1.089 & 1.481 & 1.027 & 0.936 \\
\hline & 1.973 & 1.969 & 1.955 & 1.946 & 1.951 & 1.959 & 1.957 \\
\hline & 2.742 & 2.598 & 2.739 & 2.575 & 2.342 & 2.599 & 2.637 \\
\hline \multirow{6}{*}{$\begin{array}{l}\text { Soluble-K } \\
\text { Exchangeable-K } \\
\text { Plant available-K }\left(\mathrm{H}_{2} \mathrm{SO}_{4}\right) \text { extraction } \\
\text { Fixation capacity } \\
\text { Potassium intensity }\end{array}$} & \multicolumn{7}{|c|}{ Three- Year Rotation } \\
\hline & 0.025 & 0.048 & 0.025 & 0.025 & 0.064 & 0.037 & 0.033 \\
\hline & 0.448 & 0.488 & 0.384 & 0.410 & 0.448 & 0.436 & 0.427 \\
\hline & 0.801 & 0.821 & 0.801 & 0.821 & 1.280 & 0.905 & 0.814 \\
\hline & 1.969 & 1.965 & 1.968 & 1.961 & 1.968 & 1.966 & 1.965 \\
\hline & 2.761 & 2.889 & 2.761 & 2.739 & 2.417 & 2.713 & 2.796 \\
\hline \multirow{6}{*}{$\begin{array}{l}\text { Soluble-K } \\
\text { Exchangeable-K } \\
\text { Plant available-K }\left(\mathrm{H}_{2} \mathrm{SO}_{4}\right) \text { extraction } \\
\text { Fixation capacity } \\
\text { Potassium intensity }{ }^{* *}\end{array}$} & \multicolumn{7}{|c|}{ Fertilizer effect } \\
\hline & 0.036 & 0.042 & 0.038 & 0.046 & 0.071 & 0.047 & 0.042 \\
\hline & 0.624 & 0.607 & 0.667 & 0.705 & 0.739 & 0.668 & 0.660 \\
\hline & 0.895 & 0.883 & .927 & 1.045 & 1.337 & 1.017 & 0.952 \\
\hline & 1.975 & 1.966 & 1.964 & 1.959 & 1.958 & 1.964 & 1.963 \\
\hline & 2.695 & 2.712 & 2.694 & 2.611 & 2.426 & 2.628 & 2.672 \\
\hline
\end{tabular}

* FYM: Farmyard manure **Potassium intensity: $\mathrm{p} \mathrm{K}-0.5 \mathrm{p}(\mathrm{Ca}+\mathrm{Mg})$ 
It is evident that the K-values of soluble, exchangeable and plant available ( $\mathrm{H}_{2} \mathrm{SO}_{4}$ extraction) forms are higher in case of the one-year rotation compared with the other two rotations where cotton was grown yearly in such plots. This system of cropping results in poor vegetative growth in conjunction with less $\mathrm{K}$ removal by plants and consequently higher soil $\mathrm{K}$ content compared with the other rotations.

On the other hand, both the two- and three- year rotations plots were cultivated with cotton, wheat, maize and berseem having different root systems and nutrient requirements. This cropping system furnishes suitable media for more growth and crop production which result in relatively more depletion of plant nutrients.

\subsection{Potassium retention capacity.}

The soil capacity for $\mathrm{K}$ retention depends mainly on soil clay content, where a large amount of $\mathrm{K}$ is fixed by clay minerals present in soil and cannot be taken up by plants to achieve optimum plant growth (Abdul-Wakeel and Muhanned 2013) the existing potassium level in soil is also highly considered in this respect.

Data shown in Table (3) reveal that there exists a distinct decrease in potassium forms of soluble, exchangeable and plant available in case of the two- and three-year rotations compared with the one-year rotation. This decrease did not affect the soil capacity of $\mathrm{K}$ retention where the average value of $\mathrm{K}$ retention is mostly the same and reached $1.968,1.959$ and $1.966 \mathrm{meq} / 100 \mathrm{~g}$ soil for the one- , two- and threeyear rotations respectively. In this respect, Von Reichenbach (1957) showed that the fixation process becomes more prominent, the greater the extent to which the micas have been impoverished in potassium. Zanaty (1970) also found that the intensive cropping of soils resulted in a distinct decrease in potassium forms and consequently the fixation capacity of exhausted soils increased.

\section{2- Potassium status in soil as affected by farmyard manure and mineral fertilization.}

\subsection{Farmyard manure.}

The annual applications of farmyard manure resulted in increasing the soil $\mathrm{K}$ content of all potassium forms in case of the three different rotations. The soil $\mathrm{K}$ content in case of the farmyard manure treatment is mostly higher than the treatment receiving NPK. This trend exists in case of all the studied rotations.

Also, the $\mathrm{K}$ release determined by $\mathrm{H}_{2} \mathrm{SO}_{4}$ extraction is higher in case of farmyard manure applications than NPK applications. Moreover, the soil capacity for retaining potassium is similar to the other treatments. 


\subsection{Mineral fertilization.}

Data shown in Table (2) indicate that the cropping system followed in case of the different rotations governs the impact of applying the mineral fertilizers treatments on soil potassium status. For instance, values of soluble- $K$, exchangeable- $K$ and $\mathrm{H}_{2} \mathrm{SO}_{4}$ extracted $-\mathrm{K}$ are higher in case of the one-year rotation compared with the low values existing in case of the two- and three-year rotations. The mean Kvalues using $\mathrm{H}_{2} \mathrm{SO}_{4}$ reached $1.104,0.935$ and $0.814 \mathrm{meq} / 100 \mathrm{~g}$ soil in case of soils receiving mineral fertilizer for the one-, two- and three-year rotations, respectively, where the higher values exist in case of the one-year rotation. Moreover, the application of NPK treatment resulted in increasing the values of the other different $\mathrm{K}$ forms compared with NP treatment.

\section{3- Potassium intensity.}

The values of labile- $\mathrm{K}$ availability measured from the activity ratio $[\mathrm{a} \mathrm{K} \mathrm{a}(\mathrm{Ca}+$ $M g)^{-1 / 2}$ ] for the soils of Bahtim permanent experiment are shown in Table (3), where they follow the same trend of different $\mathrm{K}$ forms values. Moreover, the activity ratio value is relatively low in case of the one-year rotation and increased in both the twoand three-year rotations.

Meanwhile, the impact of $\mathrm{K}$ application on the $\mathrm{K}$ availability is evident in case of NPK treatment, where the intensity value indicates potassium adequacy compared with the intensity values of NP treatment. This trend holds true for all the different rotations.

On the other hand, FYM application affected clearly the intensity values in all rotations, where it represents $\mathrm{K}$ adequacy levels.

The values obtained in this study furnish information on the potential reserves of available potassium in case of the alluvial soils. Monitoring changes in potassium availability could help in predicting the expectation of crop response to potassium applications.

\section{REFERENCES}

1. Abdul-Wakeel, Mehreen G. and S. Muhanned . 2013. Potassium dynamics in three alluvial soils differing in clay contents. Plant growth, Emir. J. Food. Agric. 25 (1): 39-44.

2. Aladjem, R. 1952. Results of the permanent manuring experiments of the Royal agricultural society at Bahtim with special reference to the effect of continuous application of nitrate of soda on the soil. Royal Agric. Soc., Egypt, Bull 940, 1952. 
3. Barber, S. A. 1984. Soil nutrient bioavailability: A mechanistic approach. John Wiley \& Sons New York.

4. Beckett, P. H. T. 1964. Potassium-calcium exchange equilibria in soils: Specific adsorption sites for potassium. J. Soil Sci., Vol. 97, pp. 376.

5. Behera, S. K., D. Singh and B. S. Dwivedi . 2009. Changes in fraction of iron, manganese, cupper and zinc in soil under continuous cropping for more than three decades. Comm. Soil Sci. Plant Ana. 40: 1380 - 1407.

6. El-Damaty, A. H. and T. El-Baradhy. 1956. Results of the permanent manuring experiment at Bahtim on crop yields from 1950-1955. Ann. Agric. Sci. Fac. Agric., Ain Shams Univ. Vol: 1, No: 1,143-153.

7. Fayed, R. I. and K. R. Rateb. 2013. Long term cropping system impacts on some physical and chemical properties and fertility status in alluvial soil of Egypt. Alex. J. Agric. Res. Vol: 58, No. (1) 9-18.

8. Hamdi, H. R., H. El-Damati and M. Zanati. 1971. A comparative study for determining potassium supplying power of the soils in Egypt. J. Soil, Sci. U.A.R. 11:205.

9. Heggi , S. E. 1976. Some physical studies on the plots of the permanent experiment at Bahtim. M. Sc. Thesis Fac. Agric. Al- Azhar Univ., 1976.

10. Hunter , A. M. and P. F. Pratt. 1957. Extraction of potassium from soils by sulphuric acid. Soil Sci. amer. Proc., 21:595-597.

11. Madaras, M. and J. Lipavsky. 2009. Interannual dynamics of available-K in longterm fertilization experiment. Plant soil environs. 55(8); 334-343.

12. Reitemeier, R. F. 1951. Release of native and fixed non-exchangeable potassium of soils containing hydrous mica. U. S. D. A. Tech. Bull: 1049, 1951

13. Schuffelen , A. C. and H. W. Van der marel. 1955. Potassium fixation in soils. Potassium Sym. 157-201, 1955.

14. Talibundeen, O. and N. Rajendran. 1969. Extraction of potassium from soils by exchange resins. Pep. Rothamsted Experiment Station, 1969.

15. Von Reichenbach, H. G. 1957. Untersuchungen uber verteilung and Dynamik des kaliums in boden de Gottinger E. Feldes. Diss. Gottingen.

16. Woodruff, C. M. 1955. The energies of replacement of calcium by potassium in soils. Soil Sci. Soc. Amer. Proc., 19: 167-171.

17. Zanaty, M. R. 1970. Interaction between potassium and calcium in soil and its effect on plant growth. Ph. D. Thesis, Ain Shams Univ., 1970.

18. Zanaty, M. R. and H. Khalil. 2014. Bahtim permanent manuring experiment. Unpublished data. 


\section{حالة البوتاسيوم فى أراضى تجربة بهتيم المستديمة تحت ظروف الاورات الزراعية و المعاملات السمادية المختلفة}

هلى محمد رجائى محمود أحمد انشر اح ابر اهيم محمد المعاز حسين محمود خليل

$$
\text { معهد بحوث الأراضى والمباة والبيئة - مركز البحوث الزراعية - جيزة - مصر }
$$

أخذت عينات تربة سطحية مخلطة ( - . ب) من قطع التجــارب مــن أر اضــى التجربـــة

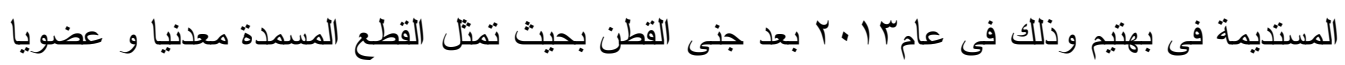

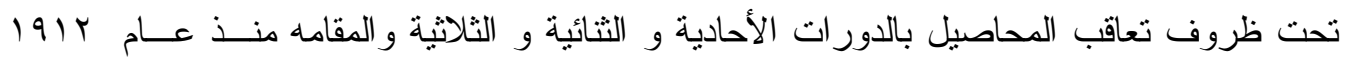

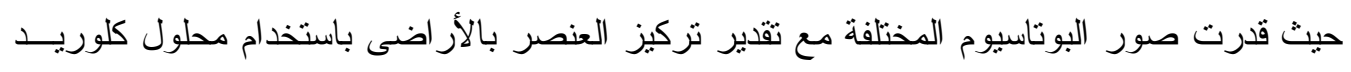

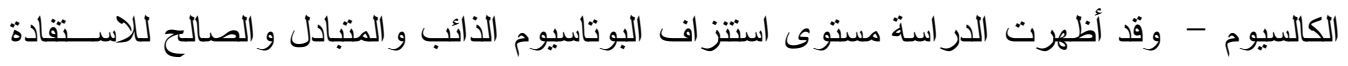
نتيجة تطبيق الدورات الزر اعية المختلفة حيث كان مستوى الاستنز اف عاليا فى حالة الدورات الثنائية

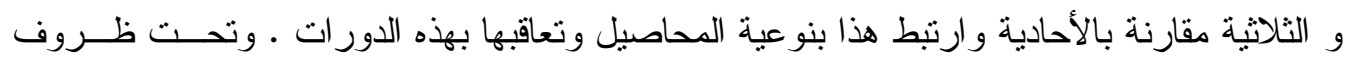

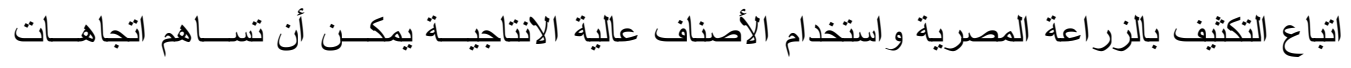

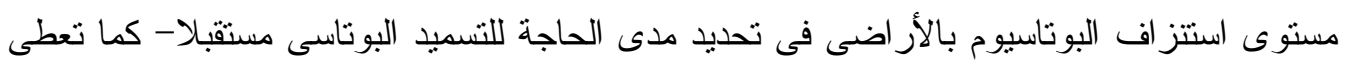
نتائج هذة الدر اسة تحت ظروف التجارب المستديمة أهمية خاصة لها فى تحديد اســــامة الانتاجيــة بالأر اضى المصرية. 